\title{
From Pillarized Active Membership to Populist Active Citizenship: The Dutch Do Democracy
}

\author{
Paul Dekker ${ }^{1,2}$ (D)
}

Published online: 5 November 2018

(C) The Author(s) 2018

\begin{abstract}
This contribution about the Netherlands to the special issue [or: section] on volunteering and civic action focuses on changes in public understanding and policy perspectives. Developments since the second half of the nineteenth century show shifting emphases on active membership (based on associational life and typical of the phenomenon of 'pillarization'), active citizenship (based more on an individual sense of responsibility and more or less political in nature) and unpaid work (volunteering as a gift to society and other people). Government policy over the last two decades has focused heavily on 'reponsibilization' of citizens, both as regards providing help to others when they need it (unpaid work/informal care) and in terms of their relationship with the society in which they live (active citizenship). We expand further on the recent notion of the 'do-democracy' as a populist and anti-political way of doing things together on a small scale instead of engaging in democratic controversies and trying to get a grip on big issues.
\end{abstract}

Keywords Netherlands - Active citizenship ·

Volunteering · Do-democracy $\cdot$ Responsibilization ·

Populism

Paul Dekker

paul.dekker@uvt.nl

Tilburg University, Tilburg, The Netherlands

2 Netherlands Institute for Social Studies I SCP, Postbus 16164, 2500 BD Den Haag, The Netherlands

\section{Framing Popular Engagement}

The aim of this paper is to help in understanding the development of dominant views on voluntary civic or social and political involvement ${ }^{1}$ in the Netherlands, and in particular the recent focus by Dutch politicians and advocates of active citizenship on the concept of 'do-democracy'. The paper is more concerned with how activities are discussed-framed, named, differentiated, loaded with intentions and functions, appreciated-than with their content and frequency. And it focuses more on how elites in politics and media see voluntary involvement and how this is reflected in public opinion, than on how active citizens describe their activities and give meaning to them.

It is useful when looking at developments in the Netherlands to distinguish between three different concepts or traditions of popular engagement: ${ }^{2}$

1. Unpaid work: doing something job-like out of a willingness to give up time for other people or society; roughly the Anglo-Saxon concept of voluntary work.

2. Active membership: doing something extra in and for an association or movement to which one belongs; the traditional Scandinavian idea of volunteering.

\footnotetext{
${ }^{1}$ I will use the term 'popular engagement' in the rest of this paper as an overarching term to describe voluntary political and non-political civic involvement as proposed by Adalbert Evers and Johan von Essen in the Introduction to this special issue.

${ }^{2}$ See Dekker (2002). The subtypes are related to various types of voluntary organizations as distinguished by Charles Handy (1997): active membership is the core of mutual support organization, active citizenship for campaigning organizations, and unpaid work for service-delivery organizations. See Brudney and Meijs for further differentiation and management implications. See Brandl et al. (2009) for a careful analysis of different meanings of volunteering and their consequences for answering identical questions about volunteering in Austria and Australia.
} 
3. Active citizenship: doing something out of a sense of duty or responsibility as a citizen, as a member of the larger community; at the core of German ideas about Ehrenamt).

I will use this threefold concept of popular engagement to describe changing practices and discourses in the Netherlands from the nineteenth to the twenty-first century in 'Developments up to the 1990s' section. After a brief European comparison of types of engagement in 'Intermezzo: Civic Ideals and Activities in Comparative Perspective' section, in 'A Civil, Caring and Responsible Society and Do-democracy' sections, I will look in more detail at the present situation and in particular the concept of 'do-democracy'. 'The Problems of Depoliticized Active Citizenship' section continues with a discussion of depoliticization of popular engagement in this concept, and 'Outlook' section concludes with a more speculative reflection on the future of popular engagement in the framework presented in the Introduction to this special issue by Evers and Von Essen.

\section{Developments up to the 1990 s}

I will very briefly summarize the history up to the last decade in a number of broad, overlapping periods. ${ }^{3}$

1870-1960: This was the golden age of Dutch 'pillarization', although it is less typical than the Dutch would like to believe. 'Pillarization' is the vertical segregation of different population groups along religious or political lines. It is the result of bottom-up and top-down building of associations and linking existing organizations into blocs. Catholic organizations formed the most encompassing and homogeneous pillar. The Protestants or Calvinists were also strongly pillarized, but in several pillars, ranging from a loose liberal Protestant cluster to several tighter orthodox clusters. The liberals and the socialists formed smaller, more partial pillars of their own as a reaction to the confessional pillarization. The different pillars had their own hospitals, burial funds, newspapers and broadcasting associations, social and economic interest organizations, women's organizations, choirs and soccer clubs. Calvinists and Catholics also had their own schools; the socialists and liberals were content with the state schools. Private schools existed long before pillarization, but they became important organizations in the confessional pillars. From the

\footnotetext{
${ }^{3}$ For these sections, I draw heavily on Dekker (2015), in which references to the English and Dutch literature can be found. For other histories of Dutch civil society and the voluntary sector see Burger and Veldheer (2001), Habraken et al. (2013) and Brandsen and Pape (2015). For more context see Lijphart (1968), Bax (1988) and Kennedy (2017).
}

eighteenth century onwards, municipalities began founding state schools and the national state became more involved in education. Government gradually increased the support for state schools, but did not provide funding for private schools, arguing that state schools had a general Christian character. This provoked opposition from Catholics and Calvinists, who did not want to pay taxes for state schools and also have to pay for their own private schools. Their struggle for equal treatment of state and private schools was finally rewarded by the 'pacification' of 1917, a historical compromise between liberals and confessionals. Liberals acquired universal suffrage, and confessionals received full recognition and equal financial rights for private schools in the Constitution of 1920. This laid an important foundation for the 'politics of accommodation' (Lijphart 1968) with publicly funded private action as a dominant modus in other fields and a growth model for the post-war Dutch welfare state.

Pillars were the result of a great deal of voluntary action (more so among Protestants and socialists than Catholics, who were organized in a more top-down way, and liberals, who probably felt less need to organize in order to realize their goals). The pillars primarily mobilized 'active members' - devoted adherents- to be disciplined, to spread the word, to perform all kinds of services for their community. That was perhaps primarily the male role; women were probably more involved in the unpaid work role, closer to care in the private sphere; active citizenship was primarily a role for the liberals/bourgeois outside the pillars. The pillars linked forms of civic involvement and provided civic education: people could start as a member of a religious youth organization or sports club and progress through to board membership, become active in interest organizations and end up as professional politicians. There was no great tension between social and political involvement, but there were clear gender roles.

1945-1975: Growth of the welfare state. Based on the pacification and the confessional principles of subsidiarity and sphere sovereignty, the development of the welfare state after the Second World War led to the expansion of publicly financed but privately delivered welfare state services, such as health care, welfare work, housing and media. Pillarization provided the organizational framework for the development of the welfare state, with policy guidelines such as the acceptance of extensive freedoms of action of the pillarized organizations and proportional representation and distribution of facilities between the pillars. However, the successful partnership with a growing welfare state was not without consequences for the function and character of the pillarized institutions. As service industries, they modernized, increased in scale and professionalized. The population secularized, and the ideology and denomination of organizations became less and less 
relevant. The networks of pillarization eroded for this reason, and also because 'interpillar' mergers and initiatives were considered necessary to improve the quality of the services and to meet new, specific needs. As regards volunteers, there was a transformation on the one hand from active members to board members dealing with professionals and on the other a much larger group of volunteer helpers working for professionals. Active membership survived in the spheres of leisure, advocacy and politics, but unpaid work became the dominant type of volunteering in the major welfare state sectors of care, education and social work.

1975-present: Reform and replacement of the welfare state. In the 1970s, the legitimacy of confessional organizations in a secularized country, the organizational and professional autonomy and the costs and fragmentation of services became topics of debate. The crisis in public finances of the late 1970s and early 1980s led to efficiency measures and further large-scale mergers, reducing the autonomy of non-profits and leading to the disappearance of many pillarized organizations. Reforms were directed towards cutbacks in public expenditure, slimming down the civil service, territorial and functional decentralization, privatization and deregulation. Many non-profit organizations felt the need, or were forced, to reorganize, scale down or commercialize due to the decreasing levels of government funding. In addition, deregulation meant the end of the non-profit monopoly in certain areas and gave newcomers the opportunity to enter domains previously dominated by monopolistic non-profits. Besides these shifts between the types of organizations delivering the services of the welfare state, recent decades have shown a growing emphasis on the need to reduce publicly funded professional services by encouraging pure private arrangements, calls for more 'self-responsibility' and urging people to seek more support from their own informal networks, and revitalizing old forms of mutual help and encouraging new ones. Government and local authorities also became more directly involved in stimulating volunteering. Churches, interest organizations and other voluntary associations became less effective for the mass mobilization of volunteers and had to be supported and compensated, including by publicly financed volunteer centres (Van den Bos 2014).

I will return to these innovations in the next sections and will conclude this section with a look at the changes in political involvement. Until the 1960s, and up to the present for shrinking confessional segments of the population, political behaviour was very much a part of pillarization. 'Doing politics' was an integral element of running civil society organizations. People first grew into positions as amateur politicians, later progressing to full-time public authorities through umbrella organizations and political parties representing their pillar. Since the mid-1960s, we might trace two phases of political participation.

1965-1990: This was a period of new political and social movements, developed outside the pillars and often heavily inspired by international topics and examples. This generated new forms of political action (occupations, sitins) and conflicts between activists and representatives of vested interests. There was also a movement making things more 'political' (the personal is political, lifestyle politics), not only on the secular left, but also among churchgoing religious people: the Third World, the environment and nuclear weapons were issues for social and political action, for changing individual behaviour, for community activities and protests. Besides this area of new politics, but sometimes related to it, were attempts to democratize official politics and formal institutions by introducing consultation procedures in policymaking and giving a say to clients of welfare state services. This created more representative and consultative bodies with more formal options for participation by politically active citizens.

1990-present: These are the years of growing frustration about democratization and consultation procedures: they take a lot of time and are often used by the usual suspects ('higher-educated (sometimes angry) older white men'), burdensome for the administration and 'just fake' in the eyes of critical citizens. This is leading to new experiments with interactive policymaking and 'co-producing' active citizens in smaller groups, but often with the same frustrations. Politicians, however, feel the need to get more 'ordinary citizens' involved as a contribution to closing the gap between government and people. Closing an assumed widening gap was a major concern around 1990 and again in 2002 (the revolt by Pim Fortuyn), and again about 10 years later, with Geert Wilders as the successful populist polarizer of 'the elite' versus 'ordinary people'. 'No votes in two national referenda in the Netherlands (in 2005 against the European constitution and in 2016 against an agreement between the EU and Ukraine) demonstrate at the very least widespread political discontent and perhaps a gap, but not a new wave of political activism. They are primarily successes by small groups of political entrepreneurs, helped by exploiting the possibilities offered by (social) media. Part of the political energy of activists is moving away from formal politics to advocacy organizations, initiatives to influence enterprises and consumers and citizen initiatives. There are growing difficulties in finding enough active citizens to be voted on to representative bodies, etc.

Summarizing the developments so far, it can be said that popular engagement was heavily encouraged as a means of active membership in the pillarized society. Volunteering continued to be an important part of Dutch civic life—and has kept the Netherlands in a top position internationally as 
regards the number of volunteers (Dekker 2013)—after the pillars and voluntary associations had lost much of their strength. Volunteering increasingly developed into unpaid work, with strong development of active citizenship from the 1960s onwards in separate spheres of new politics.

\section{Intermezzo: Civic Ideals and Activities in Comparative Perspective}

In this section, I will present quantitative information from two European population surveys which place popular engagement in the Netherlands in a comparative perspective. First of all, the ideals of citizenship: how important is the ideal of active citizenship and how has it changed? Table 1 presents findings from the Citizenship modules of the 2004 and 2014 editions of the International Social Survey Programme (ISSP). People were asked to say on a 1-7 scale (transformed into 0-100 for Table 1) how important they felt nine features of good citizenship were. In this and the subsequent tables, the features are ranked according to their average importance in the countries included in the table. Besides the Netherlands in both years, all other countries in this special issue are included for 2014. To make it easier to compare the relative importance of the features, I also show deviations from the national average.

In the two Nordic countries, voting is the most important characteristic of a good citizen; in the other countries, it is obeying the law, including tax obligations. Neither boycotting and buycotting nor international solidarity is seen as great civic virtues by most people in the seven countries studied. 'To be active in social and political association' is the least popular everywhere. ${ }^{4}$

Comparing the public in the Netherlands between 2004 and 2014/15, there are no major changes, but there is rather more support for obeying the law and less support for some other aspects. There is definitely no swing to more active citizenship; being active in social and political organizations is still at the bottom, and critical consumerism and voting slip down the rankings somewhat.

In Fig. 1, we compare two rather low threshold measurements of volunteering and political involvement. The volunteering might include political activities and what is called 'political activities' include consumer behaviour and

\footnotetext{
${ }^{4}$ We find similar results with similar questions in other surveys. In the European Social Survey of 2002/03, six aspects were presented. In the countries compared, 'form their own opinion, independently of others', 'vote in elections' and 'always obey laws and regulations' competed for first place; 'be active in politics' was the least popular, preceded by 'be active in voluntary organizations', which also scored below average everywhere; 'support people who are worse off than themselves' scored above average everywhere (Dekker 2013).
}

might include non-political associational involvement. However, overall, the figures will tell us something about the amount of popular involvement and whether there is more stress on volunteering or on civic action and politics.

The regression line in Fig. 1 divides the more social/ volunteering countries from the more political/civic countries. Of the countries in the special issue, the Netherlands is the most social, Sweden the most political country.

\section{A Civil, Caring and Responsible Society}

The idea of civil society has been heavily promoted by the government in the Netherlands in recent decades, but with different meanings. On the one hand, civil society is simply seen as non-government, where 'self-responsible' citizens are expected to look after their own affairs, without public help. On the other hand, and more important today than a few years ago, civil society is presented as the ideal of a 'caring society' or a 'big society', in which people feel more responsible for their fellow citizens in need and for their neighbourhoods.

Ideas of a 'caring' and 'responsible society' have been part of the Christian-democratic ideology and agenda since the 1980s. 'Civil society' became the ideal of liberal and labour politicians alike in the 1980s and 1990s, in part as an alternative framing of the corporatist 'societal midfield' colonized by former pillarized organizations and the playing field of the Christian-democrats, but increasingly seen as an alternative to government involvement and to publicly funded facilities and care. Driven by ideological motives, lack of public money, frustrating experiences with broadening and deepening state-related democracy, a kind of broad political consensus developed about the (actual/ preferable) very limited capacities of government and the need to make 'society' stronger. In 2004, a government policy paper (Cabinet 2004, p. 5) describes the 'good citizen' as follows:

"The government has in mind a citizen who is selfreliant, mature and involved, not primarily turning to the government to meet their requirements, complaints and appeals, but rather in social self-organization and initiatives."

and introducing new legislation in 2004 on social support, it states (quoted in Verhoeven and Tonkens 2013, p. 423):

"The Cabinet would like to see people behaving responsibly. This means taking responsibility according to one's own ability in a self-reliant way and with as much choice as possible: to be aware of the costs of services; care for fellow citizens; participation in civil associations and volunteering." 
Table 1 Importance of nine features of a good citizen ${ }^{a}$ in the Netherlands and six other countries in 2014/2015 (and 2004)

\begin{tabular}{|c|c|c|c|c|c|c|c|c|c|}
\hline & \multicolumn{3}{|c|}{ Netherlands } & \multicolumn{6}{|c|}{ Other countries $^{\mathrm{b}} 2014 / 15$} \\
\hline & 2004 & $\Delta^{\mathrm{c}}$ & $2014 / 5$ & DE & DK & SE & ES & UK & US \\
\hline (Average importance of all nine traits) & $(71)$ & & $(72)$ & (69) & $(72)$ & (74) & (79) & (73) & (77) \\
\hline Always to obey laws and regulations & 8 & + & 10 & 12 & 12 & 10 & 8 & 18 & 13 \\
\hline Never to evade taxes & 4 & + & 10 & 13 & 11 & 11 & 12 & 18 & 13 \\
\hline $\begin{array}{l}\text { To try to understand the reasoning of people with different opinions from your } \\
\text { own }\end{array}$ & 11 & - & 8 & 4 & 4 & 4 & 6 & 7 & 2 \\
\hline To keep watch on the actions of government & 6 & & 6 & 0 & -1 & 7 & -4 & 4 & 8 \\
\hline Always to vote in elections & 8 & - & 6 & 5 & 18 & 14 & -2 & 4 & 5 \\
\hline To help people in [your country] who are worse off than yourself & 3 & & 3 & 5 & 2 & -2 & 9 & 1 & 3 \\
\hline To help people in the rest of the world who are worse off than yourself & -2 & - & -9 & -8 & -12 & -8 & 0 & -14 & -16 \\
\hline $\begin{array}{l}\text { To choose products for political, ethical or environmental } \\
\text { reasons, even if they cost a bit more }\end{array}$ & -17 & + & -15 & -7 & -12 & -7 & -6 & -14 & -12 \\
\hline To be active in social and political associations & -21 & & -20 & -24 & -23 & -28 & -21 & -24 & -17 \\
\hline
\end{tabular}

${ }^{a}$ Deviations from the national average for all nine traits on a scale from 0 ('not at all important') to 100 ('very important') in reply to the question 'There are different opinions on what it takes to be a good citizen. As far as you are concerned personally ... how important is it ...'. Features are ranked according to their importance in the Netherlands in 2015. The most important feature(s) percountry is/are shown in bold

${ }^{\mathrm{b}}$ The other countries of this special issue: $\mathrm{DE}=$ Germany, DK $=$ Denmark, SE = Sweden, ES = Spain, UK = United Kingdom and US = United States

${ }^{\mathrm{c}}$ Significant changes $(p<.01)$ from 2004 to 2015

Source: ISSP citizenship modules 2004 and 2014 (in DK, NL and US some of the interviews took place in 2015), population aged 18 years and older, weighted results

The idea of 'responsibilization' of citizens has been at the heart of policy changes this century (Tonkens 2011), not just in the Netherlands (Trnka and Trundle 2014) and not just in relation to social policies. Shamir (2008) uses the term for the economic domain: government regulation as a form of collective coercion is to be replaced by responsible behaviour of individual firms. Shamir analyses this as a moralization of the market and argues that this further sustains, rather than undermining, neoliberal governmentalities.

There is a strong emphasis on individual responsibility in the Netherlands. Verhoeven and Tonkens (2013), comparing the British 'Big Society' with Dutch citizen-activating policy documents, find more 'empowerment talk' in Britain and more 'responsibility talk' in the Netherlands, often implying negative ideas about most citizens:

"Dutch responsibility talk blames citizens, does not grant citizens more influence over local matters, sounds fatigued and dutiful, focuses on individual citizens, and conveys a feeling that it is appropriate to have negative feelings about other citizens, that citizens should feel bad if they do not do the 'normal' thing, that participation is a duty, and that active citizenship is about 'you' and 'your' contribution to society." (Verhoeven and Tonkens 2013, p. 423).
'Self-responsibility' has become a buzzword in Dutch politics. It includes responsibility for other people, for the neighbourhood, the natural environment, etc. It includes a 'we-responsibility', as long as the 'we' is a concrete social entity or identifiable group and not the anonymous society or the state. ${ }^{5}$ Another term used to stress this is the "participation society'. It was used in the King's speech at the start of the parliamentary year in September 2013: 'The classical welfare state is slowly but surely evolving into a "participation society"'. The term was received in the media as something new if not revolutionary, but it was actually used long before this by social-democrats and Christian-democrats, and it is not really any different from earlier ideas about a 'caring' and 'responsible' society.

The 'end of the welfare state' is an exaggerated interpretation of recent developments, but things are definitely changing. Most important for the majority of citizens are the changes in social security schemes, pensions (financial,

\footnotetext{
5 The ideas are very close to the notorious 'there is no such thing as society' statement by the then British Prime Minister Margaret Thatcher in 1987. It is worth looking up this statement made in an interview in Women's Own magazine (http://www.margaretthatcher. org/document/106689). It was not a hyperindividualistic denial of society, but an emphasis of the responsibilities of individuals and social associations which now, 30 years later, would have been able to appear in a Dutch policy paper without anyone batting an eyelid.
} 


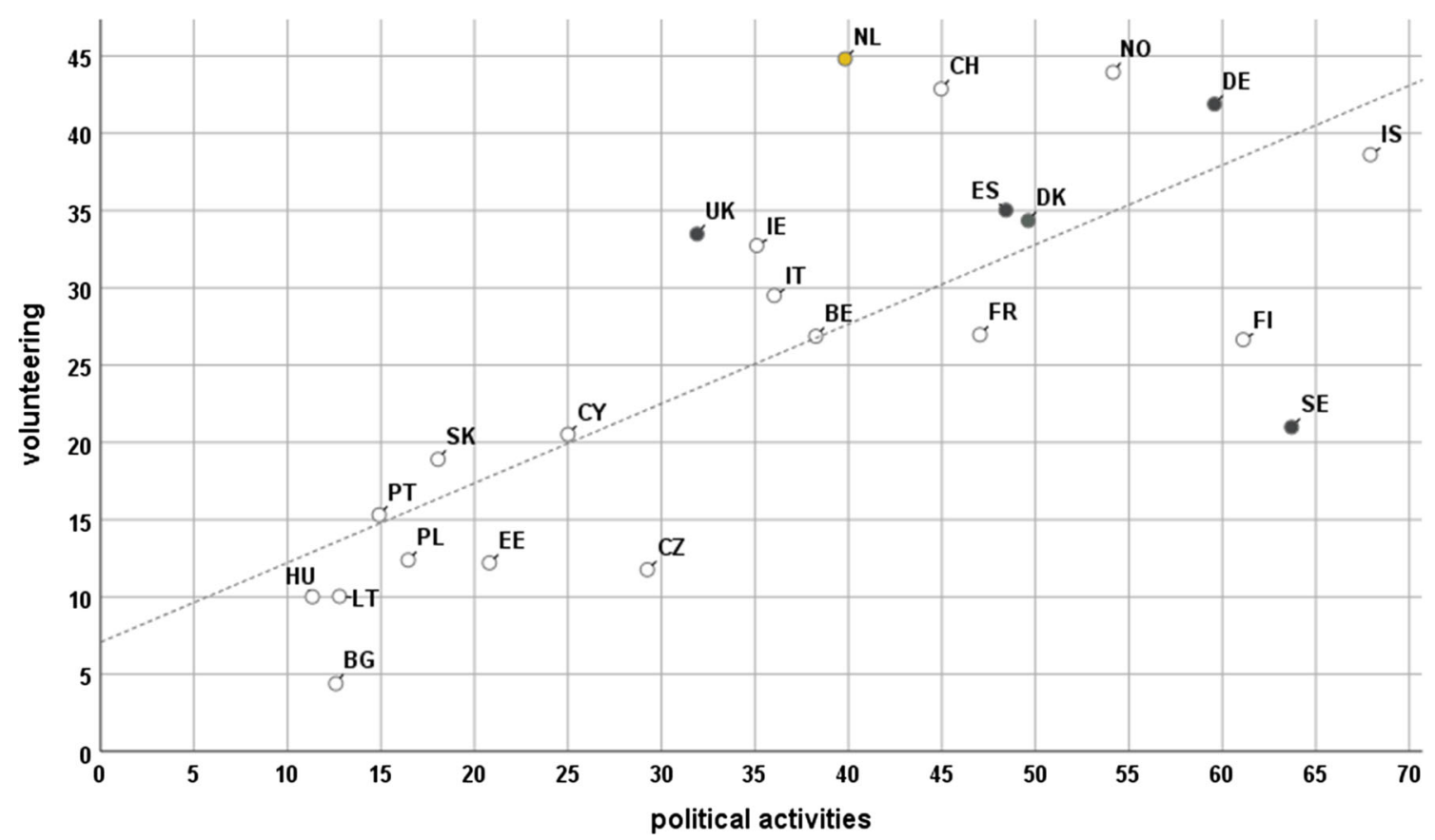

Fig. 1 Involvement in volunteering ${ }^{a}$ and political activities ${ }^{b}$ in The Netherlands and 22 other countries ${ }^{\mathrm{c}}$ in 2012/' 13 . 'Volunteering: 'In the past 12 months, how often did you get involved in work for voluntary or charitable organizations'? Reported are the percentages answering 'at least once every six months'. 'Political activities: 'There are different ways of trying to improve things in [country] or help prevent things from going wrong. During the last 12 months,

retirement age) and financial arrangements for housing, study, etc. The formerly tax-funded non-profit sector, aka civil society organizations, has become more dependent on other financial means or has to compete for public money with commercial organizations.

Nowadays, both policymakers and citizens talk less about volunteering than about citizen or civic participation ('burgerparticipatie'). The terminology of volunteers and volunteering is still used for (1) what many people do in sports clubs, etc. (some as active members, others as responsible members/clients, not always voluntary but as a membership condition) and (2) as something temporary because 'somebody has to do it' (wash the dishes, write a letter, etc.; it is less about 'being a volunteer'). The 'unpaid work' idea is nowadays more something for people who are unable to do paid work: something to help reintegrate them into the labour market, or as a community duty expected from people who receive social assistance. Active citizenship is perhaps the core identity of voluntary civic involvement these days, but emptied of its political and critical content. The ideal is self-reliant participation, not policy-influencing participation. The first of these refers to forms of participation which mainly involve people doing something themselves, such as keeping their neighbourhood clean or keeping a service or amenity running. The have you done any of the following? ...' Reported are the percentages involved in at least one of the following five (from a list of seven) possibilities: contacted a politician, government or local government official/worked in a political party or action group/worked in another organization or association/taken part in a lawful public demonstration/boycotted certain products. ${ }^{c}$ The other European countries in this special issue (see Table 1) in grey. Source: European Social Survey 6

second is about exerting influence on the policy of a public or private body, for example by voting, lobbying or exercising the right to public consultation and participation in decision-making. Current government policy in the Netherlands is aimed particularly at promoting the former, i.e. self-reliant civic participation. ${ }^{6}$

Summarizing the developments of popular engagement until the 2010s from a dominant policy perspective, the main change may have been a shift in focus from volunteering in general to voluntary (health) care ('informele zorg'/informal $\mathrm{care}^{7}$ ) and to neighbourhood activities ('burgerparticipatie'/citizen participation). The political call to the population is in both cases about taking responsibility for people and services in one's living environment.

\footnotetext{
${ }^{6}$ As has been noted in particular in the field of social and health care, responsibilization and self-reliance are one side of the coin, the other being intrusive policies aimed at people who behave 'irresponsibly'. See Tonkens (2011), who analyses simultaneous processes of responsibilization and deresponsibilization in this field.

7 The vocabulary is somewhat confusing: caring activities are 'informal' from the perspective of health care professionals and policymakers, but 'formal' from the traditional Dutch volunteering perspective, where volunteering is by definition carried out for or through an organization as opposed to unorganized informal help) (see the indicators in Fig. 1).
} 


\section{Do-democracy}

A policy concept that is closely related to the reintroduced notion of 'participation society' was also presented in a policy document in 2013 (Cabinet 2013), namely the 'doedemocratie' (do-democracy). ${ }^{8}$ Van de Wijdeven (2012) used the term earlier in his $\mathrm{PhD}$ research on active citizenship in neighbourhoods, where he identified different circuits of people involved in political participation-advisory boards, co-production of policies, protests-on the one hand and groups of practical do-it-yourself people on the other. He defined do-democracy ${ }^{9}$ as a type of participatory democracy, in which citizens are '(co-)creating the public sphere, not by deliberating, voting or bargaining, but by realizing concrete projects in the public domain of their neighbourhood'. Van Wijdeven's study showed that tangible activities appeal to citizens more than traditional political activities. People involved in them learned new skills, developed self-confidence and built new social contacts. Working together to achieve concrete improvements strengthened the social cohesion in neighbourhoods.

The eponymous policy document published by the Dutch Ministry of the Interior (Cabinet 2013) describes 'do-democracy' as a new phase in the relationship between citizen and government. After the civic policy consultations of the 1970s and the interactive policymaking of the 1990 s, at the heart of this, 'third generation' of citizen participation is doing things for oneself. According to the policy document, this no longer 'has to be done through the filter of political representation'. In fact it goes further, stating that politics and government should seek to engage with active citizens, trust them and learn to "let go".

'Do-democracy' stresses 'real' activities as opposed to 'just talking', and polarizes active citizens versus bureaucratic government (often including politicians and representative bodies). Important fields of activity for the dodemocracy are initiatives by citizens to take over public facilities such as libraries and swimming pools, arrangements to look after streets and parks, etc., but also setting up cooperatives for wind energy and energy-saving projects, or cooperatives for home care and mutual support. On the local level, coalitions of active citizens and politicians/civil servants are trying to create more space for civic

\footnotetext{
8 The terms are sometimes used as interchangeable equivalents, but do-democracy is a narrower concept focusing on voluntary civic involvement, whereas the 'participation society' includes participation in education and the labour market.

9 But not using this term in English; his own translation of the title of his book was 'democracy of action'; later on he and others (Verhoeven et al. 2014) wrote about 'do-ocracy' as it was used before by Chen (2009) to characterize activism based on individuals taking initiatives and responsibilities with informal coordination more than formal democratic decision-making (cf. (Christensen and Strømsnes 2010).
}

initiatives. There are courses to teach civil servants 'to sit on their hands', municipalities are supported by the national Ministry of Internal Affairs to leave more to citizens.

A recent meta-study of research on 125 citizen's initiatives of grassroots organizations in the Netherlands (Mensink et al. 2017) shows an enormous diversity, ranging from small-scale arrangements for providing better care and social services for family members and alternative restaurants, via groups for managing green spaces and playgrounds or offering support to undocumented immigrants, development aid projects independent of the large NGOs in this field, or wind power and other sustainable energy initiatives that are independent of vested energy suppliers or involve more or less cooperative experimental relationships. In many cases the core of the activities is the delivery of services, be it as a critical alternative to public and commercial services or as a means of coping with cutbacks in mainstream amenities and services. Advocacy and political action are secondary or not relevant at all. Some might receive subsidies from central government or use personal care budgets or social insurance funds to finance their work, others might ask for contributions from users or develop commercial activities; many will turn to local authorities for some financial support or support in kind. Most initiatives probably take the form of foundations (a very simple legal device in Dutch law), but there are also associations, and various authors have noticed a growing number of cooperatives. ${ }^{10}$ However, there is no way to take a reliable guess at the trends in total numbers of initiatives and people and money involved (cf. Mensink et al. 2017). Some reports give the impression of steady or even explosive growth, but the frequently recurring and identical 'just examples' and the complete lack of interest in initiatives that disappear after a while make one somewhat sceptical about the supposed continuous growth. For further qualitative analyses of citizens' initiatives in the Netherlands see Van Dam (2016).

In 2014 we published the results of empirical research in five Dutch municipalities, all with above-average engagement in promoting civic participation (Van Houwelingen et al. 2014). We focused on the mixtures of self-reliant and policy-influencing participation, and a short summary might give a flavour of real do-democracy. Of the five municipalities, one is encouraging its citizens, partly under pressure from spending cuts, to take over responsibility for maintaining public amenities, such as parks. Another has

\footnotetext{
${ }^{10}$ Contributions in Bokhorst et al. (2015) refer to various sources showing growing numbers of - new registrations of-cooperatives in (health) care, neighbourhood development, housing and sustainable energy. However, the absolute numbers are still small, the scale is small and the survival rate is probably often low. Therefore, new cooperatives are still a marginal phenomenon.
} 
for some time worked with neighbourhood and village teams made up of residents. The third, as part of the drive for 'self-governance', expects local residents to initiate and carry out projects as far as possible themselves. The fourth is a shrinking municipality which feels it has no alternative but to expect residents to do more themselves, such as looking after community centres. The fifth has engaged in an 'austerity dialogue' with residents to decide where spending cuts should fall. The first four are clearly focused on self-reliant civic participation, the fifth more on influencing policies and political decision-making. From our discussions with participants in these communities, we have distilled a number of factors from these experiences which appear to promote self-reliant civic participation: necessity (if the government does not provide public services and amenities, citizens have to take action themselves); degree of autonomy of the initiators and local authorities; support by the government; and scale (initiatives are more likely to flourish at local level and on a small scale).

Although we did find cases of small independent citizens' initiatives in our research and reports of others, governmental and societal organizations and their paid staff are mostly involved in one way or another. If they do not initiate the initiatives, they facilitate them in many ways, by offering office and meeting space, administrative support, professional advice, links to people in power, etc. There is a rich literature on civic participation projects in the Netherlands, but it will be very hard to find sustainable civic participation and initiatives without strong institutional support from (local) government and non-profit organizations. Even in quite secularized areas, churches often play an important role as initiators and providers of infrastructure for new private initiatives. It is surprising that these organizations are barely mentioned in policy documents about the 'do-democracy' or the wider 'participation society'. There might be formulations about 'citizens and their associations', but the associations are something abstract, a free choice by self-organizing individuals, not organizations with their own history and 'associational life'. It is quite surprising how little reference is made in the discussions to the history of citizen initiatives, the social ties that stem from them within and alongside the pillars, and the relationships that were established in the 'societal midfield' of private and semi-public organizations between citizens and government. It is seen as mere history by national policymakers, apparently irrelevant for the present day. Their concerns are basically about government and individual citizens.

At the local level there is clear policy interest for the relationships between citizens' initiatives and local authorities, and much research has been done in this field (e.g. Bakker et al. 2012; De Wilde et al. 2014). Here again, the interest in long-term developments and institutions is limited, however. The starting point is generally concrete experiments and often relatively new citizen initiatives; the chief sources of information are the most actively involved citizens and their counterparts in local government. Little research is carried out into the social structures in which they are embedded and there is little opportunity to trace what happens to the initiatives over time. Accountability is recognized as an issue to some degree in policy documents and in research reports about projects. Several small-scale studies suggest that active and inactive citizens often agree about what has to happen in their neighbourhood (Verhoeven et al. 2014, p. 12-13). Active citizens are aware of possibly different wishes of non-involved citizens and of possible negative external effects of their activities, and they are keen to obtain support and try to be accountable (Van de Wijdeven 2012; Bakker et al. 2012; Verhoeven et al. 2014). A dilemma for local government is having to choose between overly onerous heavy forms of accountability or no accountability at all (Blijleven 2016).

Coming back to our threefold concept of popular engagement, from the perspective of 'do-democracy' we see a strong focus in both government policy and research (which is often dependent on that policy) on active citizenship, with active membership being virtually ignored. Volunteers doing unpaid work are somewhere in the background of the policy documents and research reports: necessary to make things happen but probably too dependent on receiving guidelines and orders from genuinely active citizens or (worse) paid professionals to be the real heroes.

\section{The Problems of Depoliticized Active Citizenship}

In recent times, we have observed shifts between forms of voluntary civic involvement, culminating in the promotion of an unpolitical or even anti-political idea of participating in a do-democracy. In Table 1 we saw that political engagement plays a very subordinate role in the Dutch public's perception of good citizenship. ${ }^{11}$ It was certainly

\footnotetext{
$\overline{11}$ Additional evidence can be found in Dutch research in which open questions are used to ask what 'a good citizen' does and does not do. The responses suggest that politics is even less important than when measured with closed questions. If people are asked about voting, they may conform to the moral duty, but to come up with voting themselves is quite another matter, and less usual. According to our open questions the most important quality of a good citizen is being a social person: not being a burden to others, having a positive attitude (tolerance, understanding) and also doing good for others. People mention volunteering, more in an informal sense of helping others than in the formal sense of doing things for or in organizations. Besides this social side, there is the aspect of obeying the law, not driving too fast, not committing crimes, etc. A large majority of
} 
not the case that politicians enjoyed greater esteem between 2004 and 2015; on the contrary, turning out to vote was considered less important for a good citizen and obedience as a subject more important. The declining significance of politics and government for a good society has also characterized politics itself in recent decades. With references to the blessings of the market and of communities, to the small margins of action for (national) politics in the wake of Europe and globalization, and to the limited successes and high costs of earlier government policy, politics has made itself smaller and smaller and constantly sought to temper expectations across a broad front (cf. Crouch 2004).

In the ideal of 'do-democracy', a number of things come together: resentment towards the overrepresentation of highly educated people and the dominance of the usual suspects in the talking democracy; broadly shared perceptions of the ineffectiveness of policy dialogue and consultations; the need by the government to temper expectations of politics, for example because of budgetary problems and EU rules; and especially the desire on the part of active citizens to make a real difference and to develop collective responsibilities in their immediate living environment.

Research at local level on the functioning of the dodemocracy (De Wilde et al. 2014; Van Houwelingen et al. 2015) reveals major risks and limitations, however. In the first place, there is the risk that being forced to do something will put pressure on the traditions and values of voluntariness and democratic choice. Several Dutch municipalities have for example decided to close or stop subsidizing libraries, swimming pools or other facilities. Citizens were faced with these faits accomplis and their only choice was whether to pick up the gauntlet or not. That has little to do with democracy. Forced participation to fill gaps in the council budget will also do little to promote political engagement.

The second risk, as a corollary of the first, is cynicism resulting from the perceived discrepancy between the expectation that citizens will take responsibility and the lack of responsibility and responsiveness on the part of the administration. Residents in several Dutch municipalities have been irritated by expensive projects carried out by the local authority, such as the building of a new town hall following municipal restructuring, leaving residents with the feeling that their involvement in these projects was not welcome and that the council was adopting a selective

\footnotetext{
Footnote 11 continued

respondents do not mention either pure politics or the intimate sphere, but rather attitudes and behaviours in the more or less public space in between. The focus is on responsibilities towards other, less wellknown citizens and towards the community as a whole. Active political involvement is not part of this (Dekker 2013).
}

approach. That again does little to promote local democracy, and for that matter little for the willingness to participate.

The third risk stems from the inherently limited scope of the 'do-democracy'. To be able to act and to avoid too much talking, citizens get involved in limited, small-scale projects. Expensive and interconnected facilities for providing education and care are beyond their reach, to say nothing of questions such as income distribution, migration and European integration. Those are too large in scale and too complex for do-democracy, but are nonetheless sources of deep discontent about political democracy. Decisions on real political themes remain the preserve of politicians, or else they highlight the impossibility of taking decisions because of economic constraints, EU policies or international agreements. Focusing on 'making a difference' in a concrete and immediate way in villages and neighbourhoods runs a real risk of putting citizens at a growing distance from wider society and the political world.

Of course, this is not an inevitable development. Dodemocracy has its tensions and contradictions as well. It might not be so easy to set politically-influencing participation apart from self-reliant participation: active citizens saving public money by doing things without reward are sensitive to politicians wasting money. Small, non-political local issues might not be that small and unrelated to big issues. It might be difficult for people to completely avoid politics when they become involved in helping refugees or want to operate a wind turbine, for example. Bottom-up initiatives might raise major controversies in local communities, which representative politics cannot leave to 'the citizens'. One group welcoming refugees and another trying to keep refugees out of the neighbourhood generate a need for a civic dialogue about justice, the distribution of the costs and benefits of local policies, etc. Unevenly distributed successes of self-reliant participation can lead to discussions about compensating policies. New political issues might arise because of unintended consequences of successful initiatives, such as extensive use of public money by new social entrepreneurs or unfair competition between new initiatives and regulated and taxed businesses.

Thus, apart from big political issues that cannot be covered by do-democracy anyway, there are tensions and challenges of do-democratic involvement which could pave the way for a broader political engagement. However, paving that way and staying on track for a longer period will be hard work (Theiss-Morse and Hibbing 2005) because keeping things small and non-political is attractive both for most politicians and many active citizens. Politicians have an interest in defending their shrinking room for manoeuvre against real popular political influence, and in keeping citizens at a "maximum level of minimal 
participation" (Crouch 2004, p. 112). People who want to make a difference as ordinary citizens have many good reasons to avoid politics - the (dirty) political domain as well as the (weary conflictual) political debates (see the Introduction to this special issue and Stoker 2006) - as has been well documented in ethnographic studies of volunteer groups (Eliasoph 1998; LeBlanc 1999; Bennett et al. 2013; Guenther 2017; Malafaia et al. 2017).

Avoiding politics is at the heart of do-democratic rhetoric: we basically want the same things (improvement of facilities, a safe and clean living environment, etc.) and if we do not agree on specific issues, it is better to look pragmatically for a win-win solution than to embark on debates about injustice and inequalities, and social and economic conditions we cannot change anyway. ${ }^{12}$ Dodemocracy is also a deeply populist idea, assuming evident common interests of ordinary people and the superfluity of discussion, downplaying the need to find compromises and to protect minority interests, ridiculing 'elitist' and 'bureaucratic' intermediary institutions. It is quite surprising that research on populism in Western-Europe is booming but that the populism in civic engagement receives hardly any attention. Most authors on populism seem to be so obsessed by right-wing xenophobic populist parties that they cannot see the broader populist undercurrent, also manifesting itself in civic engagement and democratization ideas traditionally closer to the left. ${ }^{13}$ Not so for Margaret Canovan: after dealing with the radical populist mobilization against partitocrazi in established democracies, she formulates its affinities with radical democrats as follows:

“... many of the themes of populism are eerily familiar to any contemporary political theorist. Where else have we come across furious revulsion against pragmatic party politics and its compromises? Where else schemes for returning democracy to the grassroots and empowering the people? Where else calls for transparency and directness in the relation between popular will and democratic act, for the overcoming of alienation? Where but in the theories of participatory democracy that emerged out of the radical movements of the 1960s and have dominated philosophical discussion of the subject ever since?" (Canovan 1999, p. 15).

\footnotetext{
12 The aversion to controversies is broader and can also be noted in stressing the benefits of 'dialogues instead of debates' in the so-called G1000 citizens' summits, in which citizens discuss the biggest problems in their locality (Boogaard and Michels 2016, p. 73 ff.). These summits are seen as forms of deliberative democracy separate from the d0-democratic framework.

13 The situation is different in the American populism tradition and authors such as Harry Boyte and Peter Levine do use the term populism as a positive concept of civic renewal (see Boyte 2007).
}

There is no room left for this in this paper, but broadening the perspective it would be interesting to investigate the similarities and differences between Dutch do-democracy and 'participatory populism', as developed by Matthew Rhodes-Purdy from studying Venezuela under Chávez:

"Participatory governance grants citizens not merely a voice in politics but the ability to make some decisions directly. Yet the scope of such programs is inherently limited by geography: due to the difficulty of enacting macro-level participatory governance, such programs generally operate at the neighborhood level. As a result, their policy domain is confined mostly to basic-needs issues and community development. ... These programs allow populists to devolve power, thus meeting their commitments to empowerment and preserving the legitimacy of their regimes. I call this strategy, where local-level participatory governance is provided to legitimate national-level populist hegemony, participatory populism." (Rhodes-Purdy 2015, p. 418)

\section{Outlook}

Let me conclude and get back to the three types of popular engagement or voluntary civic involvement I started with. Since the second half of the twentieth century we have seen a shift from active membership, embedded in pillarized associational life, to more individualized active citizenship and more business-like organized unpaid work. ${ }^{14}$

As regards public policies, the main trend in recent decades-definitely in terms of rhetoric and to a lesser degree (and with contradictions) at the level of concrete measures-has been from policy-influencing participation to self-reliant do-democratic ideals, although there are also attempts to further develop deliberative mini-publics. Instead of supporting volunteering in general, there are now diverging policy goals regarding (1) stimulating informal care, merging informal help and formal volunteering into a broader category of unpaid work (a concern for the Ministry of Health); (2) stimulating active citizenship to run neighbourhood services (a focus of the Ministry of the Interior); and (3) volunteering as a means of leading people to paid work, in order to get something back from

\footnotetext{
14 Active membership is still alive and may sometimes even be on the rise in minority groups such as orthodox Protestants and immigrant groups. Mosques and Christian immigrant churches often play a central role in organizing social life and mutual support, generating a lot of organized and informal voluntary efforts. Initiatives may have the spirit of self-reliance of the old Dutch pillars, but they are far too marginal, local and partial to see them as part of new societal pillars.
} 
social security benefit recipients, to socialize school pupils, to integrate refugees, as an alternative to imprisonment, etc. (out of our scope because it is not really voluntary, or not voluntary at all).

Political activism, once the protest wing of old pillarized social movements and the core business of new social movements and individual active citizenship from the 1960s onwards, has lost its lustre in recent decades. It is perceived as ineffective and dismissed as being negative rather than constructive. Political activism is still in the toolbox of advocacy NGOs and it might still happen incidentally to express public indignation, for instance in (copies of) the 'Occupy' activities a few years ago or in local protests against refugee centres. It is highly ritual, or mainly a rapid outlet for anger, but as far as I can see is not part of any new social and political movements. Instead there seems to be a shift towards more activism on the market, be it as producers (social entrepreneurs), consumers (boycotting, buycotting), or combinations of both roles (prosumers, energy cooperatives). On the other hand, there might be more citizens' initiatives and neighbourhood activities to take care of local communities, more or less fitting into a do-democratic policy frame. In any event, the upper left quadrant of the scheme (Fig. 1) developed by Evers and Von Essen in the Introduction to this special issue is not the place where I would expect to see many active volunteering Dutch citizens in the near future. I might be wrong, because the internal tensions of politics avoiding engagement could lead to a re-politicization of do-democratic involvement in neighbourhoods and in providing local facilities. This is the politicization from below scenario about which Evers and Von Essen speculate. But I might also be wrong because of another possibility, namely mobilization and politicization from above on global issues falling outside the do-democratic domain. That might equally well involve 'right-wing' issues about immigration and national interests, as 'left-wing' issues concerned with economic inequality and sustainability transitions. The upper left quadrant of Evers and Von Essen's figure might then be filled with followers of political entrepreneurs and media visionaries, entirely separate from the active citizens at the bottom right.

\section{Compliance with ethical standards}

Conflict of interest The author declares that he sees no conflict of interest.

Open Access This article is distributed under the terms of the Creative Commons Attribution 4.0 International License (http://crea tivecommons.org/licenses/by/4.0/), which permits unrestricted use, distribution, and reproduction in any medium, provided you give appropriate credit to the original author(s) and the source, provide a link to the Creative Commons license, and indicate if changes were made.

\section{References}

Bakker, J., Denters, B., Oude Vrielink, M., \& Klok, P. J. (2012). Citizens' initiatives. Local Government Studies, 38(4), 395-414.

Bax, E. H. (1988). Modernization and cleavage in Dutch society. Groningen, NL: Universiteitsdrukkerij.

Bennett, E. A., Cordner, A., Taylor Klein, P., Savell, S., \& Baiocchi, G. (2013). Disavowing politics. American Journal of Sociology, 119(2), 518-548.

Blijleven, W. (2016). Accountable do-ocracy. Utrecht: Universiteit Utrecht, Master Thesis Public Administration and Organizational Science.

Bokhorst, M., Edelenbos, J., Koppenjan, J. F. M., \& Oude Vrielink, M. (2015). A new kid in town. Burgercoöperaties. Bestuurskunde, 24(2), 1-62.

Boogaard, G., \& Michels, A. (Eds.). (2016). G1000. Den Haag: Boombestuurskunde.

Boyte, H. C. (2007). "We the people" politics. Dayton: Kettering Foundation.

Brandl, C., Gross, M., \& Haller, M. (2009). Participation in voluntary activities in Austria and Australia. In M. Haller, R. Jowell, \& T. W. Smith (Eds.), The International Social Survey Programme 1984-2009 (pp. 409-430). London: Routledge.

Brandsen, T., \& Pape, U. (2015). The Netherlands: The paradox of government-nonprofit partnerships. VOLUNTAS: International Journal of Voluntary and Nonprofit Organizations, 26(6), 2267-2282.

Brudney, J. L., \& Meijs, L. C. P. M. (2014). Models of volunteer management: Professional volunteer program management in social work. Human Service Organizations: Management, Leadership \& Governance, 38(3), 297-309.

Burger, A., \& Veldheer, V. (2001). The growth of the nonprofit sector in the Netherlands. Nonprofit and Voluntary Sector Quarterly, $30(2), 221-246$.

Cabinet (2004). Kabinetsvisie 'Andere overheid'. Den Haag: Tweede Kamer 2003/4, 29.362, \#1.

Cabinet (2013). De Doe-democratie. Kabinetsnota ter stimulering van een vitale samenleving. Den Haag: Ministerie van BZK.

Canovan, M. (1999). Trust the people! Populism and the two faces of democracy. Political Studies, 47(1), 2-16.

Chen, K. K. (2009). Enabling creative chaos. Chicago: University of Chicago Press.

Christensen, D. A., \& Strømsnes, K. (2010). Democracy or do-ocracy. In E. Amnå (Ed.), New forms of citizen participation (pp. 147-160). Baden-Baden: Nomos.

Crouch, C. (2004). Post-democracy. Cambridge: Polity Press.

De Wilde, M., Hurenkamp, M., \& Tonkens, E. (2014). Flexible relations, frail contacts and failing demands. Urban Studies, 51(16), 3365-3382.

Dekker, P. (2002). On the prospects of volunteering in civil society. Voluntary Action, 4(3), 31-48.

Dekker, P. (2013). Dutch civil society in macro quantitative perspectives. In A. Zimmer (Ed.), Civil society compared (pp. 141-160). Wiesbaden: Nomos Verlag.

Dekker, P. (2015). Shifting ideas of subsidiarity in the Netherlands. In P. Donati \& L. Martignani (Eds.), Towards a new local welfare (pp. 113-140). Bologna: Bolonia University Press.

Eliasoph, N. (1998). Avoiding politics. Cambridge: Cambridge University Press.

Guenther, K. M. (2017). How volunteerism inhibits mobilization. Social Movement Studies, 16(2), 240-253.

Habraken, R., Meijs, L., Schulpen, L., \& Temmink, C. (2013). Dutch civil society at crossroads. Development in Practice, 23(5\&6), 742-754 
Handy, C. (1997 [1988]). Understanding voluntary organisations. London: Penguin.

Ilcan, S., \& Basok, T. (2004). Community government. Citizenship Studies, 8(2), 129-144.

Kennedy, J. C. (2017). A concise history of the Netherlands. Cambridge: Cambridge University Press.

LeBlanc, R. M. (1999). Bicycle citizens. Berkeley: University of California Press.

Lijphart, A. J. (1968). The politics of accommodation: Pluralism and democracy in the Netherlands. Berkeley: University of California Press.

Malafaia, C., Luhtakallio, E., Menezes, I. \& Neves, T. (2017). Being civic while disavowing politics. Current Sociology. https://doi. org/10.1177/0011392117704243.

Mensink, W., Van den Berg, E., Boele, A., Van Houwelingen, P., Kullberg, J., Plaisier, I., \& Schyns, P. (2017). 'A system of free societal initiatives'. In Paper for the IASC Biennial Conference, Utrecht, July 10-14.

Rhodes-Purdy, M. (2015). Participatory populism. Political Research Quarterly, 68(3), 415-427.

Shamir, R. (2008). The age of responsibilization. Economy and Society, 37(1), 1-19.

Stoker, G. (2006). Why politics matters. Making democracy work. Basingstoke: Palgrave Mcmillan.
Theiss-Morse, E., \& Hibbing, J. R. (2005). Citizenship and civic engagement. Annual Review of Political Science, 8, 227-249.

Tonkens, E. (2011). The embrace of responsibility. Citizenship and governance of social care in the Netherlands. In J. Newman \& E. Tonkens (Eds.), Participation, responsibility and choice (pp. 45-65). Amsterdam: Amsterdam University Press.

Trnka, S., \& Trundle, C. (2014). Competing responsibilities: Moving beyond neoliberal responsibilisation. Anthropological Forum, 24(2), 136-153.

Van Dam, R. I. (2016). Bonding by doing. Wageningen: Alterra, $\mathrm{Ph}$.D. thesis Wageningen University.

Van de Wijdeven, T. (2012). Doe-democratie. Delft: Eburon, Ph.D. thesis Tilburg University.

Van den Bos, C. M. (2014). Using volunteering infrastructure to build civil society. Rotterdam: Erasmus University Rotterdam, Ph.D. thesis.

Van Houwelingen, P., Boele, A. \& Dekker, P. (2014). Burgermacht op eigen kracht? The Hague: The Netherlands Institute for Social Research I SCP.

Verhoeven, I., Metze, T., \& Van Wijdeven, T. (2014). Do-ocracy's democratic anchorage. In Paper for the 42nd ECPR Joint Sessions, Salamanca, 10-15 April 2014.

Verhoeven, I., \& Tonkens, E. (2013). Talking active citizenship. Social Policy and Society, 12(3), 415-426. 